\title{
Analisis Sistem Pengendalian Temperatur WHT dalam Operasi Tunak Untai Uji FASSIP-02
}

\author{
Arif Adtyas Budiman¹, G. B. Heru', Joko P.W1, Giarno1, Mulya Juarsa1 \\ ${ }^{1}$ Pusat Teknologi dan Keselamatan Reaktor Nuklir-BATAN, \\ Kawasan Puspiptek, Gedung 80, Serpong, Tangerang Selatan 15310, Banten, Indonesia
}

\begin{tabular}{l}
\hline INFORMASI ARTIKEL \\
\hline Riwayat Artikel: \\
Diterima: \\
15 November 2019 \\
Diterima dalam bentuk revisi: \\
25 November 2019 \\
Disetujui: \\
3 Desember 2019
\end{tabular}

\section{Kata kunci:}

WHT

sirkulasi alam

termokopel tipe-K

pengendalian temperatur

CFD

FASSIP-02

\begin{abstract}
ABSTRAK
ANALISIS SISTEM PENGENDALIAN TEMPERATUR WHT DALAM OPERASI TUNAK UNTAI

FASSIP-02. Pengembangan teknologi pendingin pasif dilakukan secara intensif melalui kegiatan penelitian menggunakan Untai Uji Fasilitas Simulasi Sistem Passif (FASSIP-02). Salah satu komponen Untai Uji FASSIP-02 adalah Water Heating Tank (WHT) yang menyimulasikan bejana penghasil kalor dan memiliki empat pemanas elektrik dengan dua yang dikendalikan secara otomatis. Pengendalian temperatur WHT berdasarkan pembacaan tiga termokopel tipe-K yang dipasang gradual secara vertikal. Pengendalian temperatur WHT dalam kondisi tunak dilakukan untuk menyimulasikan keadaan nominal operasi reaktor. Tujuan penelitian ini yaitu untuk mendapatkan visualisasi dinamika fluida WHT terhadap pengendalian pemanas pada kondisi tunak. Metode penelitian dilakukan dengan melakukan eksperimen kondisi tunak yang kemudian dilanjutkan dengan pembuatan model WHT dan simulasi dinamika fluidanya menggunakan Computational Fluid Dynamics (CFD). Hasil analisis menunjukkan adanya karakteristik fluida yang berbentuk lapisan thermal pada awal pemanasan sebagai tatanan konveksi alam. Hal ini memunculkan perbedaan pembacaan temperatur aktual terhadap target. Amplitudo riak pembacaan tertinggi terdapat pada temperatur target $60^{\circ} \mathrm{C}$ sebesar $1,12^{\circ} \mathrm{C}$. Oleh karena itu, profil dinamika fluida yang diamati dari dapat menjadi referensi dalam pengaturan kompensasi temperatur pengendalian pemanas.
\end{abstract}

\begin{abstract}
ANALYSIS OF THE WHT TEMPERATURE CONTROL SYSTEMS IN A STEADY-STATE FASSIP-02 OPERATION. The development of passive cooling technology is carried out intensively through research activities using the Passive System Simulation Test Facility Strand (FASSIP-02). One component of the FASSIP-02 Test Strand is the Water Heating Tank (WHT) which simulates a heat-producing vessel and has four electric heaters with two that are automatically controlled. WHT temperature control is based on three K-type thermocouple readings that are mounted vertically. WHT temperature control in steady state is done to simulate the nominal state of reactor operation. The purpose of this study is to get a visualization of the dynamics of the WHT fluid on heating control in steady state. The research method was carried out by conducting steady state experiments which were then continued by making a WHT model and simulating fluid dynamics using Computational Fluid Dynamics (CFD). The results of the analysis indicate the presence of fluid characteristics in the form of a thermal layer at the beginning of heating as a natural convection order. This results in a difference in the actual temperature reading from the target. The highest reading ripple amplitude is at a target temperature of $60^{\circ} \mathrm{C}$ of $1.12^{\circ} \mathrm{C}$. Therefore, the observed fluid dynamics profile can be a reference in the heating control temperature compensation.
\end{abstract}

Keywords: WHT, natural convection, K-type thermocouple, temperature control, CFD, FASSIP02

@ 2019 Jurnal Pengembangan Energi Nuklir. All rights reserved

\section{PENDAHULUAN}

Pengkajian mendalam terkait sistem keselamatan reaktor nuklir sejak terjadinya kecelakaan reaktor tipe BWR di Fukushima Daiichi pada tahun 2011 hingga saat ini terus dilakukan. Pembangkit Listrik Tenaga Nuklir (PLTN) yang berada di prefektur Fukushima, dioperasikan oleh Tokyo Electric Power Company (TEPCO) dengan total sebanyak 6

\footnotetext{
*Penulis korespondensi.

E-mail: arif-adtyas@batan.go.id
}

unit. Adapun ketiga unit pembangkit, yaitu unit 4, 5, dan 6 berada dalam kondisi pemeliharaan sedangkan unit lainnya sedang beroperasi ketika tsunami terjadi. Adanya kegagalan sistem aktif akibat terjangan tsunami yang membanjiri ruang diesel pada Pembangkit Listrik Tenaga Nuklir Unit 1 menjadi suatu permasalahan penting. Pada peristiwa ini, kalor sisa (decay heat) dari bejana reaktor tidak dapat dipindahkan ke lingkungan karena pompa sirkulasi primer tidak bekerja (sistem aktif). Air 
sebagai pendingin utama bahan bakar yang berada di dalam bejana reaktor mulai berubah fasa menjadi uap, sehingga menyebabkan konsentrasi gas hydrogen yang tinggi [1].

Selain itu, akibat ketiadaan pendingin atau Loss of Coolant Accident (LOCA), temperatur bahan bakar mulai meningkat yang mengakibatkan deformasi bentuk bejana reaktor pada bagian bawahnya sampai mengalami pelelehan [2], akibat bersentuhan dengan debris elemen dan bahan-bakar nuklir. Akibatnya, produk fisi yang dilepaskan ke lingkungan sudah tidak dapat dihindari. Selain kontaminasi kea rah lapisan tanan, lepasan juga bergerak ke udara sesuai dengan arah dan kecepatan angin sehingga potensi adanya kontaminasi dapat meluas.

Menanggapi peristiwa tersebut, sistem pendingin pasif diusulkan sebagai suatu solusi mitigasi agar proses pendinginan teras reaktor tetap berlanjut hingga keadaan normal tanpa intervensi daya dari luar. Dasar dari sistem pendingin pasif yaitu memanfaatkan fenomena sirkulasi alam. Dalam hal ini, fenomena sirkulasi alam terjadi karena kondisi cairan yang memiliki perbedaan temperatur, ketinggian, dan volume tertentu dan dalam geometri tertentu dari wadah cairan/fluida. Dalam hal ini, air sebagai cairan pendingin memiliki sifat fisik yang dapat diubah oleh perbedaan temperatur selama periode waktu tertentu. Dengan demikian, keberadaan aliran fluida pendingin dapat dihasilkan untuk memenuhi sistem perpindahan kalor.

Saat ini, ada beberapa program penelitian sistem pendingin pasif sejak dekade terakhir. Penelitian terkait analisis kinerja pengungkung AP1000 selama LOCA dilakukan oleh Zhen-Yu Hung, dkk. Mereka menganalisis kinerja sistem pendingin pasif yang disebut sebagai Passive Containment Cooling System (PCCS) untuk menghilangkan panas peluruhan untuk waktu tertentu. Kode GOTHIC dan Design Control Document (DCD) digunakan sebagai alat. Menurut perhitungan dan analisis tersebut, diperoleh bahwa pengunaan PCCS selama tiga hari dapat menjaga performa containment dengan baik [3]. Penelitian lain tentang Integrated Pressurized Water Reactor (iPWR) telah dilakukan oleh Yandong Hou, dkk. Penguatan analisis komparatif air umpan dan sistem keselamatan pasif terhadap beberapa skenario kecelakaan dilakukan menggunakan kode RELAP5. Berbagai skenario seperti kecelakaan akibat kehilangan aliran atau Loss of Flow Accident (LOFA), pemadaman listrik atau Station Black-out (SBO), dan kerusakan kecil kehilangan pendingin atau Small Break Loss of Coolant Accident (SBLOCA). Hasil simulasi dan analisis menunjukkan bahwa untuk desain iPWR100 MW, adanya sistem air umpan sebagai pendingin darurat terhadap beberapa skenario tersebut mengakibatkan perpindahan kalor yang optimal ke lingkungan. Sistem ini merupakan bagian dari sistem keselamatan pasif [4].

Selain itu, Indonesia melalui unit kerja PTKRN-BATAN, juga memiliki fokus penelitian pada sistem pendingin pasif. Untuk melakukan investigasi mendalam terhadap fenomena sirkulasi alam yang dapat dimanfaatkan dalam pengembangan sistem keselamatan reaktor nuklir, berbagai fasilitas untuk mempelajari hal tersebut telah dibangun di Laboratorium Termohidrolik PTKRN-BATAN. Fasilitasfasilitas tersebut diantaranya; Untai Fasilitas Simulasi Sistem Pasif 01 (FASSIP-01), preFASSIP, Untai FASSIP-02 dan Reactor Cavity Cooling System (RCCS). Program penelitian telah dilakukan terhadap beberapa skenario yang berbeda. M. Juarsa, dkk melakukan penelitian untuk memperkirakan kebutuhan air dalam Untai Uji FASSIP-02. Metode perhitungan analitik digunakan untuk memprediksi kecepatan aliran melalui hubungan geometri yang dilalui aliran dan parameter termal air. Pemanasan dilakukan pada variasi temperatur $50^{\circ} \mathrm{C}$ hingga $90^{\circ} \mathrm{C}$ dengan interval $10^{\circ} \mathrm{C}$ di Water Heating Tank (WHT). Hasilnya menunjukkan bahwa kenaikan temperatur akan berpengaruh untuk menghasilkan kecepatan aliran yang jauh lebih tinggi [5]. Penelitian lain dari Untai Uji FASSIP-02 telah dilakukan oleh A.R. Antariksawan, dkk. Metode yang digunakan melalui studi numerik untuk menyelidiki karakteristik loop Untai Uji FASSIP-02. RELAP5 digunakan sebagai alat analisis utama terhadap beberapa kasus untuk mengetahui efek diameter pipa dan fluks panas. Menurut hasil simulasi, menunjukkan bahwa diameter pipa 2 in direkomendasikan untuk mendukung variasi fluks panas [6].

Adapun hal yang berbeda pada penelitian ini, yaitu temperatur air di WHT akan dipertahankan pada kondisi tertentu melalui 
instrumentasi dan kendali. Beberapa skenario eksperimental dilakukan pada temperatur kendali (T-Set) WHT sebesar $50^{\circ} \mathrm{C}, 60^{\circ} \mathrm{C}$, $70^{\circ} \mathrm{C}, 80^{\circ} \mathrm{C}$, dan $90^{\circ} \mathrm{C}$. Pengendalian $\mathrm{T}-$ Set terhadap temperatur rerata di WHT dilakukan melalui block diagram LabVIEW yang terhubung ke modul I/O National Instrument dan dirangkai melalui Solid State Relay (SSR). Kondisi ini memungkinkan pengendalian temperatur WHT dapat dilakukan dalam kondisi tunak sehingga mampu menginvestigasi perpindahan kalor yang terjadi di Water Cooling Tank (WCT). Penelitian ini bertujuan untuk menganalisis dinamika fluida terhadap pembacaan temperatur reratanya, sehinggga, amplitude riak pembacaan dapat diminimalisir.

\section{POKOK BAHASAN}

\subsection{Water Heating Tank (WHT)}

Fenomena sirkulasi alam pada Untai FASSIP-02 dibentuk dari dua bagian utama, yaitu WHT dan WCT. Densitas air diturunkan di dalam WHT dan dinaikkan kembali setelah melewati penukar kalor berbentuk pipa $U$ di WCT sehingga aliran terbentuk di sepanjang untai [5][6][7]. Untai FASSIP-02 memiliki empat pemanas elektrik dengan daya masingmasing sebesar $5 \mathrm{~kW}$ yang diposisikan saling berhadapan seperti pada gambar 1 [8].

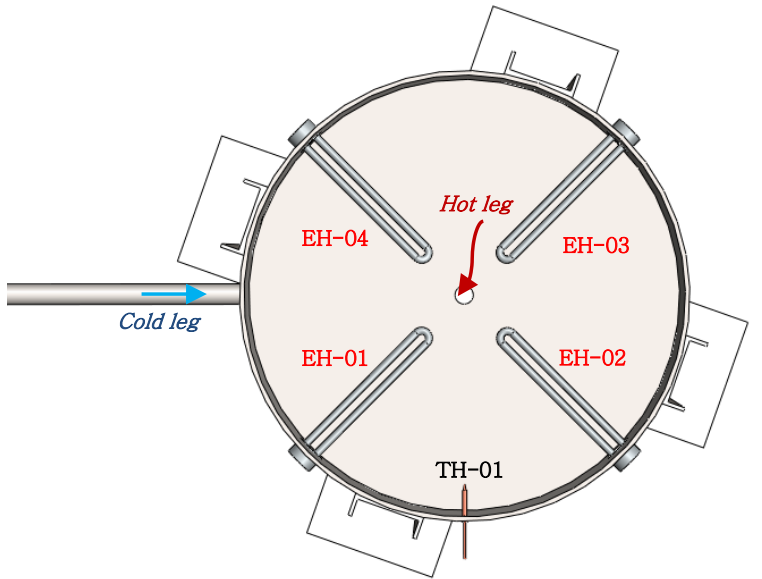

Gambar 1. Tampilan irisan WHT dari atas.

Pada Gambar 1., dipaparkan alur pemipaan cold leg yang berada di bagian bawah WHT dan hot leg di atasnya. Jalur cold leg memiliki temperatur fluida yang lebih rendah dari WHT dan berasal dari keluaran WCT. Sementara itu, hot leg merupakan jalur fluida bertemperatur lebih tinggi dari WCT. Diantara EH-01 dan EH-02 terdapat konfigurasi termokopel tipe-K yang disusun vertikal pada tingkatan tertentu. Tiga termokopel tipe-K yaitu $\mathrm{TH}-01, \mathrm{TH}-02$, dan $\mathrm{TH}-03$ diposisikan pada kedalaman sekitar $40 \mathrm{~mm}, 60 \mathrm{~mm}$, dan $80 \mathrm{~mm}$ dari permukaan. Posisi tersebut dijelaskan pada Gambar 2. berikut.

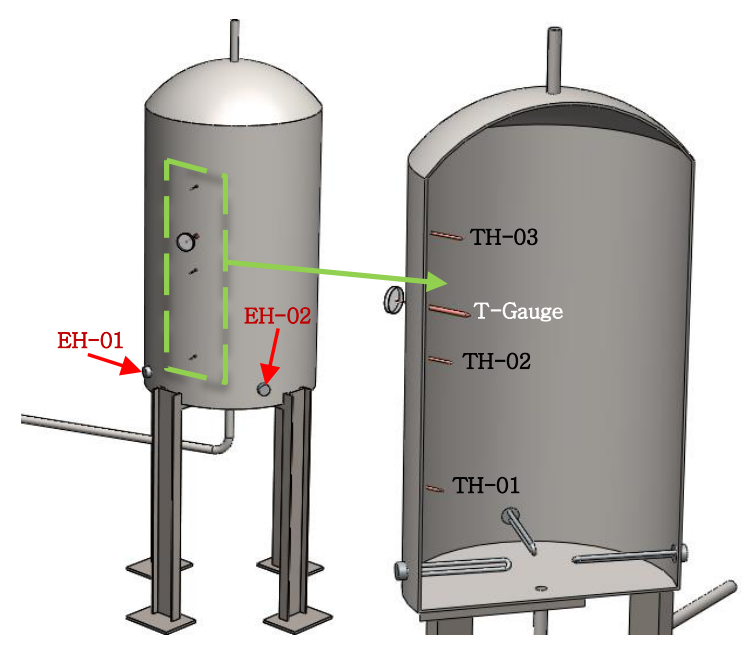

Gambar 2. Tampilan WHT dan konfigurasi termokopeltipe-K.

Posisi T-Gauge seperti yang dipaparkan pada Gambar 2., berada di antara TH-02 dan TH-03. Jarak rerata empat pemanas elektrik (EH) terhadap termokopel tipe-K pertama $(\mathrm{TH}-01)$ berkisar $70 \mathrm{~mm}$. Sedangkan dari $\mathrm{TH}-01 \mathrm{ke} \mathrm{TH}-$ 02 berkisar $310 \mathrm{~mm}$ dan TH-02 ke TH-03 sebesar $295 \mathrm{~mm}$. Adapun kesemuanya diposisikan tidak segaris terhadap $\mathrm{EH}$, melainkan menyudut $+45^{\circ}$. Sistem pengendalian keempat pemanas menggunakan modul NI9476 yang merupakan modul digital input-output. Modul ini berfungsi sebagai sakelar terprogram dan dihubungkan terhadap SSR sehingga pemanas dapat dikendalikan sesuai dengan skenario yang ditentukan. Besarnya kapasitas SSR yang digunakan yaitu 40 A. Instalasi SSR terhadap pemutus arus pemanas dipaparkan pada Gambar 3. 


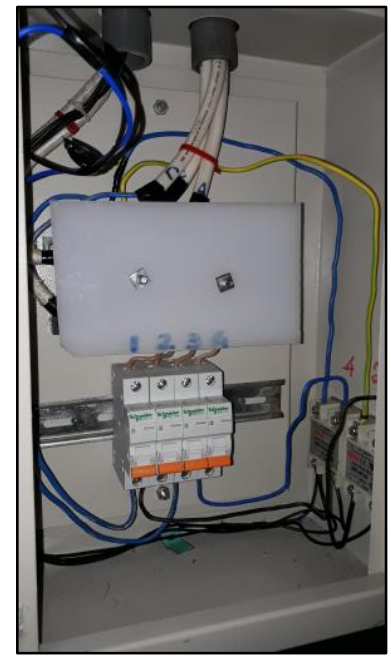

Gambar 3. Panel kendali pemanas Untai FASSIP-02.

Berdasarkan Gambar 3., dua SSR digunakan untuk mengendalikan $\mathrm{EH}-02$ dan $\mathrm{EH}-04$ secara otomatis. Sedangkan, EH-01 dan EH-03 dikendalikan secara manual melalui pemutus arus atau Miniature Circuit Breaker (MCB) masing-masing.

\subsection{Sirkulasi alam}

Pengendalian pemanas mengakibatkan adanya perbedaan temperatur fluida di dalam WHT. Sistem perpindahan kalor secara konveksi dalam untai tertutup mengakibatkan adanya aliran berpola yang mengikuti karakteristik diameter hidrolik dan tekanan hidrostatisnya. Korelasi antara perbedaan temperatur terhadap kecepatan aliran dalam sirkulasi alami diekspresikan melalui persamaan (1) berikut [5];

$$
v=\frac{-64 \mu L+\sqrt{(64 \mu L)^{2}+8 H g K \rho\left(\rho_{h}-\rho_{c}\right) D^{4}}}{2 \rho K D^{2}}
$$

Variabel L merupakan panjang pipa yang memiliki nilai D berupa diameter dalam, sedangkan $\mathrm{H}$ merupakan ketinggian yang mempengaruhi tekanan hidrostatik. Perubahan densitas air dapat diketahui dari adanya perbedaan temperatur terhadap waktu $(d \rho / d t)$. Perpindahan kalor yang terjadi di dalam WHT secara konveksi dapat membentuk lapisan atau lapisan-lapisan fluida dengan karakteristik yang beragam. Aliran yang dibangkitkan melalui konveksi alam dipengaruhi oleh Bilangan Grashof (Gr) and Reynolds (Re) diekspresikan melalui persamaan berikut [9];

$$
\frac{G r}{R e^{2}}=\frac{g \beta \Delta T L}{v^{2}}
$$

Bila fenomena yang terjadi di mana gaya apung atau buoyancy forces lebih tinggi dan melebihi rasio persamaan (2), maka Bilangan Rayleigh (Ra) digunakan dengan mempertimbangkan difusi termal (thermal diffusivity). Sehingga hubungan persamaan (2) menjadi persamaan (3) berikut ;

$$
R a=\frac{g \beta \Delta T L^{3} \rho}{\mu \alpha}
$$

dengan $\alpha=\mathrm{k} / \rho C_{p}$. Berdasarkan persamaan (3) di atas, prediksi nilai Ra yang kurang dari $10^{8}$ yaitu fenomena aliran laminar sedangkan jika nilainya berada pada rentang $10^{8}<\mathrm{Ra}<10^{10}$, aliran fluida mulai masuk pada daerah transisiturbulen.

\subsection{Sensor temperature}

Penggunaan sistem data akuisisi pada Untai FASSIP-02 melibatkan termokopel sebagai sensor pembaca temperatur melalui modul NI-9214. Termokopel tipe-K dipilih berdasarkan kemampuan pembacaannya yang sesuai dengan temperatur operasional Untai FASSIP-02 yaitu berkisar antara temperatur kamar sampai di bawah temperatur $150^{\circ} \mathrm{C}$. Kondisi di dalam WHT merupakan bagian terpanas sebelum adanya aliran yang dibangkitkan. Peningkatan temperatur dalam orde detik terhadap ketinggian WHT signifikan untuk diketahui. Sehingga konstruksi termokopel yang dibuat berbentuk bead terbuka atau exposed thermocouple agar diperoleh respon yang lebih cepat [10]. Konstruksi model ini dapat dilihat pada Gambar 4.

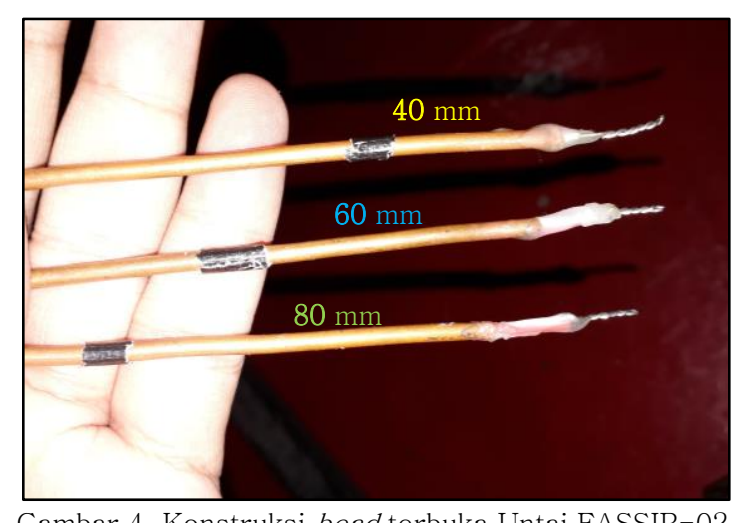

Gambar 4. Konstruksi bead terbuka Untai FASSIP-02. 
Konfigurasi posisi termokopel tipe-K di WHT dibuat gradual dengan fungsi untuk dapat mengkaji distribusi kalor secara radial.

Evaluasi pengendalian pemanas difokuskan pada rerata temperatur WHT dan hubungannya dengan temperatur rerata di WCT melalui distribusi kalor di dalam untai. Untuk dapat melihat fenomenanya secara detail melalui simulasi CFD, pemodelan dan simulasi dibuat dan diverifikasi terhadap data eksperimen.

\section{METODOLOGI}

\subsection{Kerangka eksperimen}

Kegiatan eksperimen dilakukan dengan mengaktifkan keempat pemanas sampai mencapai temperatur target. Adapun temperatur target ini mengikuti skenario yang dipaparkan dalam Tabel 1., berikut ;

\begin{tabular}{cc}
$\begin{array}{c}\text { Tabel 1. Skenario Pengendalian Pemanas WHT [11] } \\
\begin{array}{c}\text { Target Termperatur } \\
{\left[{ }^{\circ} \mathrm{C}\right]}\end{array}\end{array}$ & $\begin{array}{c}\text { Mode Pengoperasian EH } \\
{[\%]}\end{array}$ \\
\hline 50 & 50 \\
60 & 50 \\
70 & 75 \\
80 & 100 \\
90 & 100 \\
\hline
\end{tabular}

Program pengendalian pemanas diberikan melalui fungsi logika dengan termperatur rerata WHT sebagai acuannya. Apabila temperatur acuan sudah mencapai temperatur target, maka arus listrik menuju pemanas yang dikendalikan akan diputus sesuai dengan skenario pada Tabel 1 . Besarnya 50\% atau dua pemanas aktif mengindikasikan bahwa pemanas yang dioperasikan meliputi $\mathrm{EH}-02$ dan $\mathrm{EH}-04$ di mana telah memiliki jalur pemutus arus otomatis (melalui SSR). Sedangkan pada rentang nilai $75 \%$ atau tiga pemanas aktif, yang digunakan meliputi EH-02, EH-03, dan EH-04. Keempat pemanas akan diaktifkan semua pada mekanisme pengendalian dengan $100 \%$ yaitu EH-01 dan EH-3 dibiarkan aktif sementara pengendaliannya dengan $\mathrm{EH}-02$ dan $\mathrm{EH}-04$.

Temperatur dijaga sesuai dengan batasan target untuk memperoleh kondisi tunak. Kondisi ini digambarkan sebagai reaktor yang sedang beroperasi normal pada kondisi nominal. Sehingga efektifitas penukar kalor di bagian WCT dapat dikaji lebih dalam. Mengingat bahwa terdapat konfigurasi pengendalian pemanas dan sensor termal yang melekat pada WHT, maka beberapa anomali dimungkinkan dapat terjadi di sepanjang untai.

\subsection{Pemodelan CFD 3D}

Metode pemodelan yang digunakan berbasis 3D coupled, yaitu model dengan kondisi batas berupa solid-fluid. Solid disematkan kepada pemanas dan fluid untuk air. Model dibuat berskala 1:1 dengan penyesuaian bentuk pemanas. Keempat geometri pemanas disimplifikasi ke dalam bentuk silinder dengan diameter $40 \mathrm{~mm}$. Tabel 2 menyajikan informasi geometri dan kondisi batas WHT.

Tabel 2. Geometri dan Kondisi Batas WHT.

\begin{tabular}{cccc}
\hline \multirow{2}{*}{ Komponen } & \multicolumn{2}{c}{ Dimensi [m] } & Kondisi Batas \\
\cline { 2 - 3 } & Panjang & Diameter & \\
\hline $\begin{array}{c}\text { Pemanas Elektrik } \\
\text { Selimut WHT }\end{array}$ & 0,25 & 0,04 & Wall [SOLID] \\
Inlet tube & 0,2 & 0,0508 & $\begin{array}{c}\text { Mass flow inlet } \\
\text { [FLUID] }\end{array}$ \\
Outlet tube & 0,2 & 0,0508 & Outflow [FLUID] \\
TC-01 & 0,04 & 0,006 & Wall [FLUID] \\
TC-02 & 0,06 & 0,006 & Wall [FLUID] \\
TC-03 & 0,08 & 0,006 & Wall [FLUID] \\
\hline
\end{tabular}

Data yang dipaparkan pada Tabel 2 diwujudkan melalui perangkat lunak GAMBIT versi 2.3.16. Perangkat ini digunakan untuk pembuatan geometri dan inisiasi kondisi batas. Sedangkan pemberian informasi nilai-nilai kondisi batas dilakukan melalui FLUENT versi 6.3. Dalam pembuatan geometri model, mesh yang telah dibentuk, dianalisis terlebih dulu sebelum disimpan dalam format .msh dan diberi kondisi batas. Mesh merupakan segmentasi elemen (2D) atau volume (3D) yang memiliki kapasitas nilai-nilai batas dinamika fluida. Kriteria mesh yang baik telah disajikan melalui fitur yang tersedia di GAMBIT versi 2.3.16. Tabel 3 menyajikan hasil pengujian kualitas mesh. 
Tabel 3. Karakteristik Mesh WHT.

\begin{tabular}{cccc}
\hline Parameter & Worst Element & Range & \% Quality \\
\hline Aspect Ratio & 4,00028 & $1-5$ & 80,006 \\
Edge Ratio & 4,18385 & $1-5$ & 83,677 \\
Equiangle Skew & 0,803707 & $0-1$ & 80,371 \\
Equisize Skew & 0,918076 & $0-1$ & 91,808 \\
Size Change & 8,48567 & $1-9$ & 94,285 \\
Volume & 273673 & $0-3000$ & 91,224 \\
\hline
\end{tabular}

Nilai-nilai parameter yang dipaparkan pada Tabel 3 merujuk kepada metode pembuatan mesh. Teknik meshing yang disarankan pada model coupled yaitu penyelarasan sisi face atau permukaan solidfluid yang bersinggungan. Total mesh yang dibuat pada model WHT ini sebanyak 386166 elemen. Besarnya persentase kualitas (\% quality) dihitung berdasarkan jumlah keseluruhan elemen hingga yang berada di antara nilai jangkauan awal sampai ke tengah dikurangi dengan karakteristik elemen terburuknya. Mengacu kepada hal tersebut, rerata keandalan meshing sebesar 86,895\%. Nilai ini sudah lebih dari $75 \%$ kriteria mesh yang baik untuk selanjutnya diimplementasikan informasi kondisi batasnya.

Tabel 4 memaparkan informasi kondisi batas dan solver yang diberikan melalui perangkat lunak FLUENT versi 6.3. Pada penelitian ini, simulasi dilakukan dengan memberikan nilai heat flux pada keempat pemanas dan dilakukan sampai $\boldsymbol{t}=15574$ detik. Simplifikasi perhitungan dilakukan dengan mengambil kondisi pengendalian pemanas pada temperatur target $90^{\circ} \mathrm{C}$ sehingga profil dinamika fluida di dalam WHT dapat diprediksi.

Tabel 4. Data Kondisi Batas dan Solver.

\begin{tabular}{cc}
\hline Parameter & Solver/Value \\
\hline Pressure-Velocity Coupling & SIMPLE \\
All Discretization & Second Order Upwind \\
Mass Flow Inlet $[\mathrm{kg} / \mathrm{s}]$ & $0,0319[12]$ \\
Operating Pressure $[\mathrm{bar}]$ & 1 \\
Velocity Inlet $[\mathrm{m} / \mathrm{detik}]$ & $0,0674^{*}$ \\
Iteration per time step & 20 \\
All Absolute Criteria & $10^{-3}-10^{-7}$ \\
\hline Thermal Condition & \\
\hline EH Heat Generation $\left[\mathrm{w} / \mathrm{m}^{3}\right]$ & $1,3 \times 10^{6 *}$ \\
Inlet Temperatur $\left[{ }^{\circ} \mathrm{C}\right]$ & 25 \\
\hline perhitungan analitik dengan pembulatan.
\end{tabular}

\section{HASIL DAN PEMBAHASAN}

Berdasarkan skenario eksperimen pengendalian temperatur rerata di WHT selama lebih dari lima jam, diperoleh kurva pemanasan seperti pada Gambar 4.

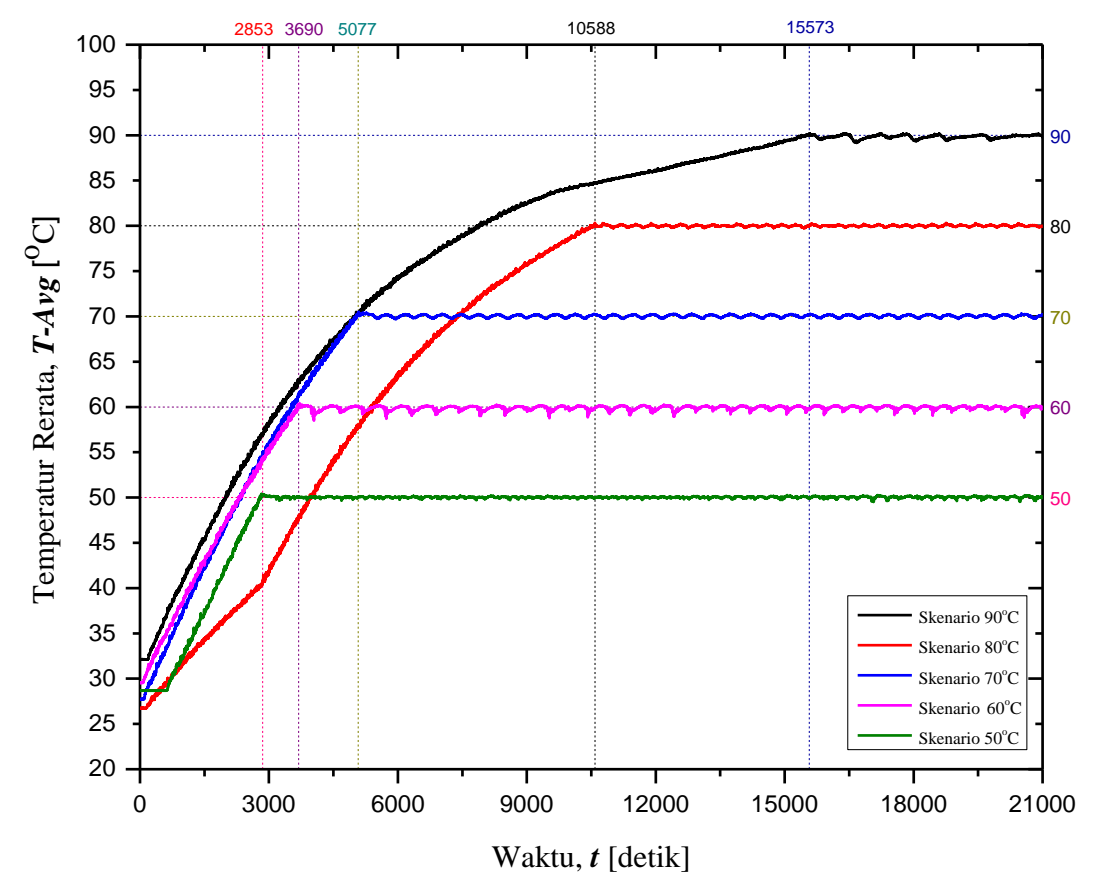

Gambar 4. Kurva pemanasan rerata WHT. 
Nilai rerata yang diambil dari $\mathrm{TH}-01$, TH-02, dan TH-03 diplotkan menjadi kurva pemanasan terhadap waktu. Kondisi awal temperatur WHT yang dipaparkan pada Gambar 4 , yaitu berkisar antara $25^{\circ} \mathrm{C}$ sampai $30^{\circ} \mathrm{C}$. Keempat pemanas dikendalikan untuk menaikkan temperatur hingga mencapai target skenario. Pada kurva tersebut, waktu capaian terendah ketika skenario pengendalian temperatur $50^{\circ} \mathrm{C}$ yaitu selama 2853 detik. Rentang waktu capaian terhadap kenaikan temperatur WHT tidaklah linear. Semakin tinggi target temperatur yang dikendalikan, semakin

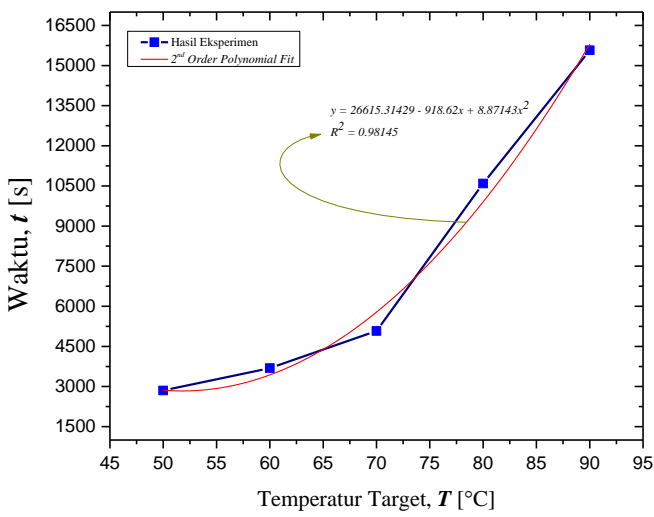

Gambar 5. (a) Profil pemanasan di WHT. lama waktu capaiannya. Hubungan ini diplotkan dalam kurva seperti pada Gambar 5(a). Berdasarkan bentuk data pengamatan, hubungan waktu terhadap temperatur mengikuti persamaan polynomial orde dua dengan $\mathrm{R}^{2}$ sebesar 0,98145. Hal ini menjadikan kurva pada Gambar 5(a) sebagai karakteristik fluida WHT jika empat pemanas aktif.

Kenaikan temperatur WHT dalam kurun waktu tertentu telah membangkitkan aliran fluida berdensitas ringan menuju alat penukar kalor sehingga temperatur WCT juga mengalami kenaikan yang signifikan.

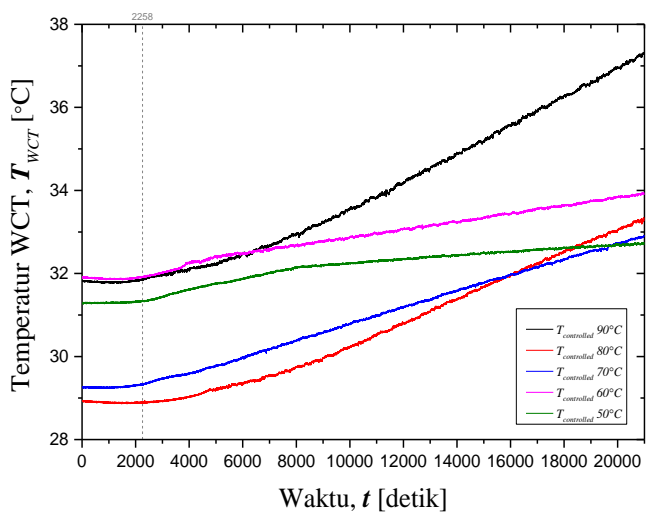

(b) Kurva kenaikan temperatur WCT.
Gambar 5(b)., merupakan kurva transien WCT pada skenario pengendalian sesuai Tabel 1 . Temperatur mulai mengalami kenaikan pada detik ke-2258 dengan kenaikan sebesar $0,01^{\circ} \mathrm{C}$ hingga $0,1^{\circ} \mathrm{C}$. Kesamaan bentuk kurva kenaikan temperatur WCT terjadi pada skenario pengendalian $80^{\circ} \mathrm{C}$ dan $90^{\circ} \mathrm{C}$. Adanya perbedaan temperatur lingkungan dan air di dalam WCT juga mempengaruhi bentuk kurva tersebut. Kurva pemanasan WHT pada Gambar 4 dengan skenario pengendalian temperatur sebesar $80^{\circ} \mathrm{C}$ memiliki pola yang unik. Hal ini disebabkan tidak semuanya pemanas aktif sampai detik ke-3000, sehingga kenaikan temperatur WCT tidak signifikan. Profil riak kurva yang terjadi pada temperatur target $60^{\circ} \mathrm{C}$, $70^{\circ} \mathrm{C}$ dan $90^{\circ} \mathrm{C}$ memiliki rentang amplitude yang relatif besar daripada profil temperatur $50^{\circ} \mathrm{C}$ dan $80^{\circ} \mathrm{C}$. Amplitudo terbesar dimiliki oleh profil kurva $60^{\circ} \mathrm{C}$ dengan nilai mencapai $1,12^{\circ} \mathrm{C}$ sedangkan pada profil kurva $50^{\circ} \mathrm{C}$ mencapai $0,4^{\circ} \mathrm{C}$. Faktor yang mempengaruhi riak temperatur yaitu aliran dan pembangkitan kalor pada pemanas yang dikendalikan.

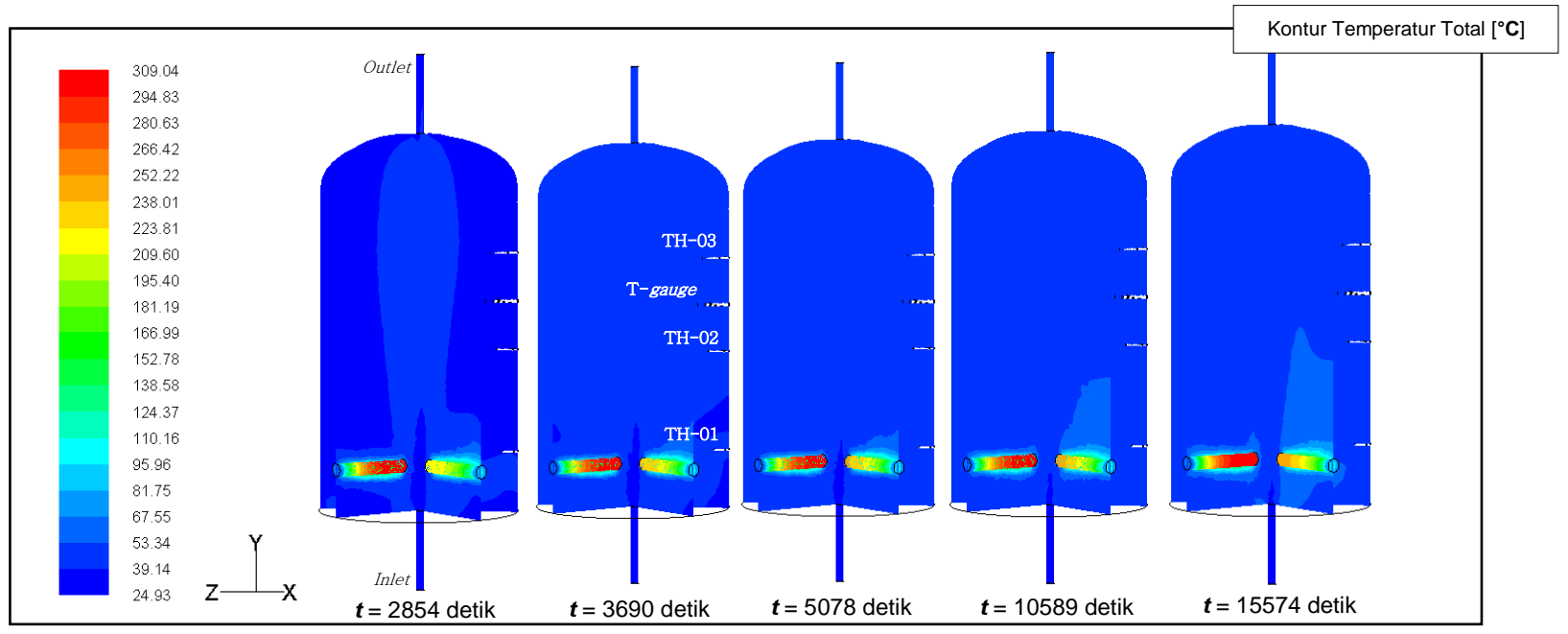

Gambar 6. Simulasi 3D profil dinamika fluida WHT. 
Simulasi CFD pada model 3D WHT memperlihatkan distribusi temperatur yang membentuk aliran konveksi. Gambar 6 menampilkan profil dinamika fluida dengan empat pemanas aktif mulai dari detik pertama sampai detik ke 2854 atau sekitar 47,55 menit waktu pemanasan sampai $\boldsymbol{t}=15574$ detik. Simulasi ini sesuai dengan kurva pemanasan WHT pada Gambar 4, yaitu saat waktu pemanasan kurang dari 2854 detik maka temperatur fluida berkisar $39,13^{\circ} \mathrm{C}$ sampai $53,27^{\circ} \mathrm{C}$. Temperatur fluida WHT mulai merata pada detik ke 5078 dengan reratanya sebesar $74,65{ }^{\circ} \mathrm{C}$. Kalor yang diterima fluida disekitar pemanas lebih banyak. Hal ini menyebabkan pada awal pemanasan, TH-01 membaca temperatur lebih besar dari $\mathrm{TH}-02, \mathrm{~T}$-gauge, dan TH-03. Pemasangan termokopel secara gradual tidak begitu mempengaruhi pembacaan temperatur axial secara signifikan. Gambar 6 juga memperlihatkan profil konveksi alam yang terbentuk ketika besarnya kecepatan inlet sebesar 0,0674 $\mathrm{m} /$ detik membawa densitas fluida ringan menuju outlet.

Daya pemanas dipertahankan pada kondisi optimal dengan input tegangan 220V selama 5 jam. Ketercapaian target pengendalian temperatur pada skenario $50^{\circ} \mathrm{C}$ dan $60^{\circ} \mathrm{C}$ telah menonaktifkan $\mathrm{EH}-02$ dan $\mathrm{EH}-$ 04, sehingga pengendalian pemanas dengan daya optimal dilakukan oleh EH-01 dan EH-03. Pada skenario temperatur pengendalian $50^{\circ} \mathrm{C}$, kalor yang diterima fluida untuk membangkitkan kecepatan aliran belum signifikan, sehingga amplitudo pembacaan pada TH-Avg tidak lebih besar dari skenario $60^{\circ} \mathrm{C}$. Namun, pada detik ke 10589 sampai 15574, distribusi temperatur di WHT mulai membentuk pola yang sama seperti detik ke 2854 sampai 3690. Dikonfirmasi oleh kurva pemanasan (Gambar 4) bahwa, pada temperatur target 60 dan 90 menghasilkan riak pembacaan dengan amplitudo besar.

Hubungan antara temperatur terhadap aliran fluida telah disimulasikan dengan simplifikasi kondisi terbuka untuk meminimalisir waktu perhitungan. Simulasi pola distribusi kecepatan aliran dipaparkan pada Gambar 7. Pengaruh perubahan temperatur terhadap kecepatan aliran saat $t=2854$ detik pada Gambar 7, menunjukkan besarnya keluaran di outlet berkisar antara 0,0627 $\mathrm{m}$ /detik hingga $0,0761 \mathrm{~m} /$ detik.

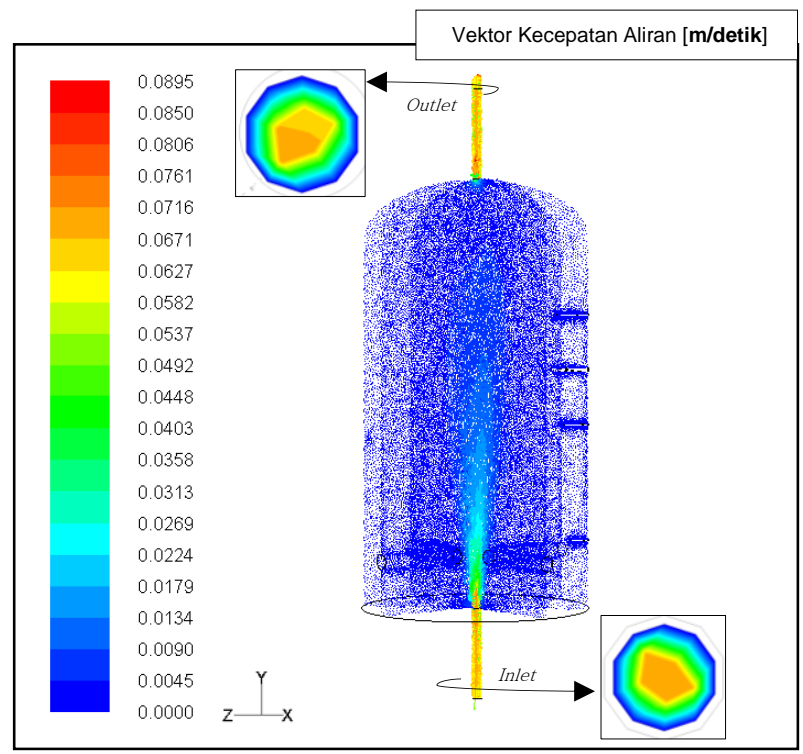

Gambar 7. Simulasi 3D profil dinamika fluida WHT.

Skenario pengendalian temperatur $70^{\circ} \mathrm{C}$ dengan satu pemanas nonaktif saat $t=5077$ detik menghasilkan profil riak yang masih lebih kecil dari pengendalian $60^{\circ} \mathrm{C}$. Satu pemanas dengan kendali manual dan dua pemanas otomatis sebagai pengendali utama mengkompensasi perubahan temperatur. Selanjutnya, pada skenario pengendalian $80^{\circ} \mathrm{C}$ dan $90^{\circ} \mathrm{C}, \mathrm{EH}-02$ dan EH-04 menjadi nonaktif saat $\boldsymbol{t}=10588$ detik dan 15573 detik secara berurutan. Kompensasi pengendalian temperatur dilakukan oleh kendali otomatis dengan kendali manual tetap aktif. Pada skenario ini, temperatur pengendalian $80^{\circ} \mathrm{C}$ memiliki profil riak yang lebih baik dari $90^{\circ} \mathrm{C}$. Pengendalian temperatur di $90^{\circ} \mathrm{C}$ melalui acuan rerata pembacaan tiga termokopel tipe-K mengalami profil fluktuasi yang unik. Nilai pembacaan di TH-01 lebih kecil daripada TH-02 dan $\mathrm{TH}-03$ diakibatkan adanya aliran fluida yang lebih cepat dan berkelanjutan dengan pola aliran lurus seperti Gambar 7.

\section{KESIMPULAN}

Pengendalian temperatur WHT berdasarkan atas pembacaan ketiga termokopel tipe-K yang diposisikan dengan jarak tertentu. Nilai pembacaan yang diacu yaitu T-Avg dengan mekanisme pengendalian pemanas secara manual dan otomatis. Pengendalian ini melibatkan skenario penjagaan temperatur pada kondisi tunak dalam waktu sekitar lima jam operasi. Adanya riak pembacaan dari data eksperimen disetiap skenario menunjukkan 
pembentukan aliran fluida. Selain itu, simulasi CFD 3D memberikan pola distribusi temperatur dan kecepatan aliran secara visual. Kecepatan aliran tertinggi pada desain WHT berada di posisi outlet dengan selisih terhadap outlet sebesar 0,7 kali nilai inlet. Pola konveksi alam dengan empat pemanas aktif dan aliran fluida berkelanjutan, menghasilkan kecenderungan aliran fluida bergerak ke arah vertikal menuju outlet, sehingga nilai kecepatan aliran di outlet lebih besar dari pada inlet. Selain daripada pengaruh perbedaan temperatur, bentuk geometri dengan adanya perbedaan luas penampang juga berkontribusi dalam meningkatkan kecepatan aliran fluida.

\section{SARAN / REKOMENDASI}

Berdasarkan analisis pengendalian temperatur WHT melalui data eksperimen dan simulasi CFD 3D, fungsi capaian temperatur target terhadap waktu dapat menjadi referensi tambahan dalam penentuan faktor kompensasi pengendalian temperatur WHT, sehingga dapat memperkecil profil amplitudo riak pembacaan pada skenario $60^{\circ} \mathrm{C}, 70^{\circ} \mathrm{C}, 80^{\circ} \mathrm{C}$ dan $90^{\circ} \mathrm{C}$.

\section{UCAPAN TERIMA KASIH}

Penulis mengucapkan terima kasih atas dukungan dari Pusat Teknologi dan Keselamatan Reaktor Nuklir Badan Tenaga Nuklir Nasional dan Kementrian Riset, Teknologi, dan Pendidikan Tinggi (KEMENRISTEKDIKTI) Republik Indonesia melalui program INSINAS Riset Pratama Kemitraan (IRPM) dengan Nomor Kontrak : 06/INS-1/PPK/E4/2019.

\section{DAFTAR ACUAN}

[1] T. Terai, "Fukushima Daiichi Accident; Causes, Lessons Learned and Current Status The University of Tokyo Born in Kobe," 2019.

[2] G. Li, M. Liu, J. Wang, D. Chong, and J. Yan, "MELCOR 2 . 1 analysis of melt behavior in a BWR lower head during LOCA and SBO accident," Ann. Nucl. Energy, vol. 90, pp. 195-204, 2016.

[3] Z. Hung, Y. Ferng, W. Hsu, B. Pei, and Y. Chen, "Analysis of AP1000 containment passive cooling system during a loss-of-coolant accident," Ann. Nucl. Energy, vol. 85, pp. 717-724, 2015.

[4] Y. Hou, M. Wang, J. Zhang, S. Qiu, G. H. Su, and W. Tian, "Comparative analysis of auxiliary feedwater system and passive safety system under typical accident scenarios for integrated pressurized water reactor (iPWR )," vol. 115, no. February, pp. 42-51, 2019.

[5] M. Juarsa, A. R. Antariksawan, M. H. Kusuma, D. Haryanto, and N. Putra, "Estimation of natural circulation flow based on temperature in the FASSIP-02 large-scale test loop facility Estimation of natural circulation flow based on temperature in the FASSIP-02 large-scale test loop facility," 2018.

[6] A. R. . Antariksawan, S. Widodo, M. Juarsa, D. Haryanto, M. H. Kusuma, and N. Putra, "Numerical study on natural circulation characteristics in FASSIP-02 experimental facility using RELAP5 code Numerical study on natural circulation characteristics in FASSIP-02 experimental facility using RELAP5 code," 2018.

[7] D. Haryanto et al., "Analisis Kekuatan Mekanik pada Desain Water Heating Tank di Untai FASSIP02," Pros. Semin. Nas. Energi Telekomun. dan Otomasi 2017, pp. 23-2, 2017.

[8] L. F. Ningsih et al., "Estimasi Perhitungan Kalor dan Laju Aliran Kalor Pada Untai FASSIP-02," Sigma Epsil., vol. 22, no. 1, pp. 26-34, 2018.

[9] I. ANSYS, “ANSYS Fluent Theory Guide," vol. 15317, no. November, pp. 724-746, 2013.

[10] A. A. Budiman, G. B. Heru, and M. Juarsa, "ANALISIS METODE PEMBUATAN TERMOKOPEL TIPE-K PADA UNTAI FASSIP02," Semin. Nas. Teknol. Energi Nukl., no. Sudah diseminarkan dan menunggu dipublikasikan pada November, pp. 1-12, 2019.

[11] G. B. Heru, Giarno, D. H, A. A. Budiman, and M. Juarsa, "Pengembangan Sistem Akuisi Data FASSIP-02 Mod-01 Berbasis LabVIEW," Semin. Nas. Energi Telekomun. dan Otomasi, no. Sudah disetujui dan belum dipublikasikan, 2019.

[12] A. R. Antariksawan, "Simulation of Operational Conditions of FASSIP-02 Natural Circulation Cooling System Experimental Loop," J. Sains dan Teknol. Nukl. Indones., vol. 19, No. 1, no. Februari 2018, pp. 41-54, 2018. 